\title{
血尿を伴った豚のポリープ性膀胱资について
}

\author{
稻田弘毅*
}

(昭和 49 年 7 月 30 日受付)

\section{Polypous Cystitis in Swine with Hematuria

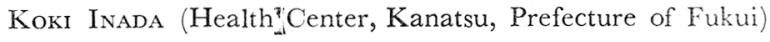

\section{SUMMARY}

Two sows were studied pathologically. Sow 1 was 7 months old and seemed to have been suffering from hematuria during life. It exhibited thickening, folding, and extensive hemorrhage of the cystic mucosa and yellowish white foci of millet size in the kidney.

Sow 2 was about 3 years old and had been suffering from severe hematuria for about a month before death. It revealed marked thickening, folding, and

\section{はじめに}

近年, 牛の膀胱血尿症が注目され, 病理学的にその膀 胼病変が論議されている。しかし，豚における血尿症例 についての報告は少ない、今回筆者は, 豚において生前 血尿症を呈していた例に遭遇しその泌尿器系を中心に病 理組織学的検索を行なったので, 概要を報告する.

\section{材料および方法}

検索した材料は 2 例で, 両例ともと畜検査の際入手し た。

第 1 例：雌, 7 力月龄, 昭和 46 年 8 月 10 日殺.

第 2 例：雙，約 3 才，昭和 46 年 8 月 10 日殺.

材料は $10 \%$ ホルマリン液で固定し. パラフィン包 埋, HE二重染色, また, 必要に応じ他の染色を実施し た.

\section{臨 床 所見}

第 1 例は不明であるが, 病理学的検索の結果から生前 血尿を排泄していたものと推測されたので検索材料に含 めた，第 2 例は生前約 1 力月間著明な血尿が認められ た.

\section{肉 眼 所 見}

第 1 例 : 膀胱には粘膜の肥厚, 䀛璧形成および広範な 出血があり, 腎臓には粟粒大黄白色限局栄を伴ら間質性 腎炎が認められた。

第 2 例 : 膀胱粘膜の高度の肥厚と炡壁形成ならびに散 在性点状出血が認められた。

\section{組織学的所見}

両例とも主要な組織学的変化は泌尿器系とくに腎臓拉

\footnotetext{
* 福井県金津保健所 (福井県坂井郡金津町高塚)
}

petechiae of the cystic mucosa and yellowish brown detritus attached to the pelvic mucosa.

Histologically, polypous cystitis was observed in both sows. In addition, interstitial nephritis and small abscesses surrounding the uriniferous tubules were noticed in sow 1 and suppurative pyelonephritis was in sow 2. Two sows may have been involved in ascending bacterial infection.

\section{よび膀脂にみられた。}

第 1 例: 膀胱粘膜上皮は増生し, 粘液変性に陥り, 粘 膜固有層および粘膜下織では充血, 出血, 水腫, 形質細 胞の高度の増数, 所によりリンパ球の集簇が認められ, 粘膜層はポリープ状に膀胱腔に突出している(図 1 ).

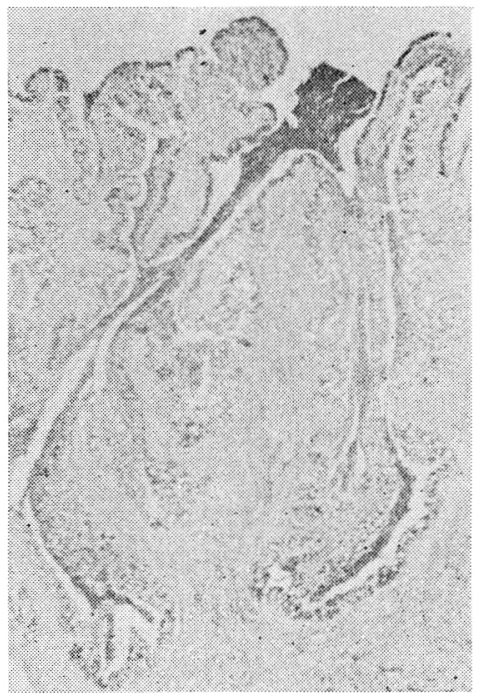

図 1 第 1 例, 膀脂, 粘膜はポリープ状に凸出 乙, 粘膜上皮は粘液変性を示す。

PAS染色 $\times 14$

腎では，慢性間質性腎焱と尿細管を中心とする小膿瘍 形成が認められた(図 2).

第 2 例 : 膀胱の変化は第 1 例とほぼ同様であるが，粘 膜上皮の增生および粘液変性は第 1 例より高度であっ た．固有層には所により線維茅細胞および組織球が増殖 し，血管の新生孔認められた(図 3). 腎では，腎孟上皮

日獣会誌 $28 \quad 77 \sim 78 \quad$ (1975) 


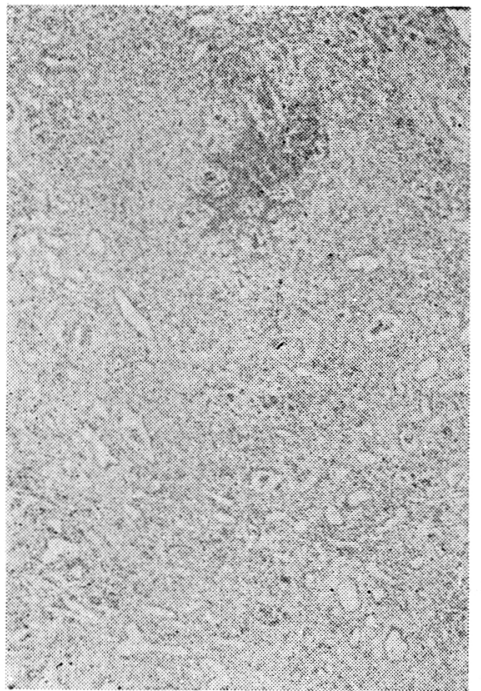

因 2 第 1 例 腎臟, 広籁な間質性腎炎と小膿 瘍の形成を示卞. $\mathrm{HE}$ 染色, $\times 28$

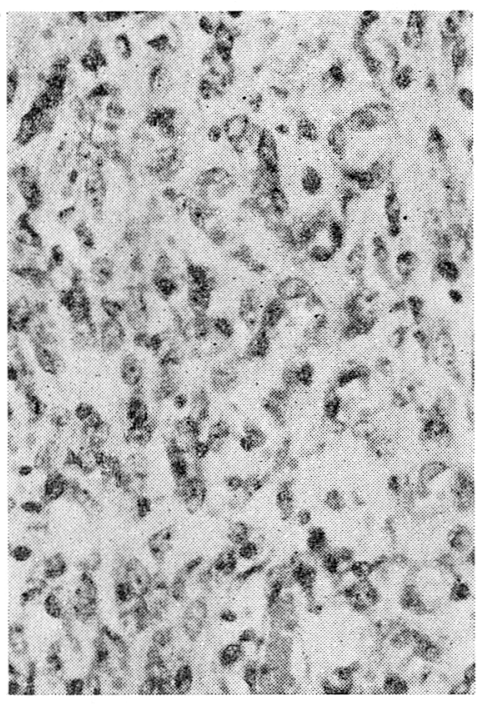

目 3 第 2 例膀脂, 固有層に打汀る血管新生 を伴う線維茅細胞抏よび組織球の增殖。

$\mathrm{HE}$ 染色， × 280

細胞は消失し，その部に菌塊をとるなった好中球を主と した細胞性頺廃物がみられ, 肉茅組織の増殖も認められ た(図 4 ). 細菌塊はグラム染色で陽性の球菌であった.

\section{考察}

両例の膀脂の組織所見はきわめて類似しており,ポリ ープ性膀脱炎と診断された，成書ではこの種の変化はと くに牛および豚では稀でなく，乙ばしばポリープ形成と 粘膜上皮細胞の粘液変性を伴らと記載されている。また，

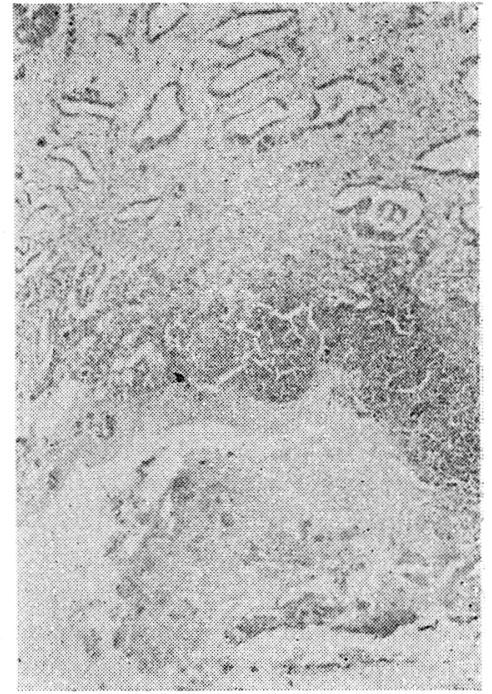

図 4 第 2 例，腎臓，化堦性腎孟腎炎を示す。 HE 染色, × 280

膀脂炎は上行性に細菌性腎孟腎炎を伴らことが多いとい。 う報告があるが，今回の第 2 例では腎臓に細菌性腎孟腎 炎を認め, これは明らかに上行性細菌感染の像であっ た. 第 1 例でも尿細管を中心として膿痬の形成がみら れ, 上行性細菌感染の可能性が強い。

今回の例に拈いては，血尿が膀胼あるいは腎孟の出血 に由来することは明らかである. 牛の血尿症に拈いて は; 単純性慢性膀胱炎や腫瘍性の変化が論議されている が，粘膜上皮の増生・粘液変性を示す例の報告はあまり 見当たらない.動物の差,あるいは原因学的な違いはある にせよ, 豚の血尿症例に抢いて粘膜上皮の増生と粘液変 性を強く示したポリープ性膀脂炎の所見は病理学的に極 めて興味深いものであると考える。

[昭和48年度日本獣医公衆衛生学会(中部) 依賞論文]

(海外文献要録)

$$
\text { 牛の気管枝癌 }
$$

H.W. Leipold, J. L. Noordsy \& J. E. Cook J.A.V.M.A, 165 (7), 628 629, 1974.

7 才齡のヘレフォードで, 創傷性第 2 胃炎の病歴があ り, 呼吸器障害が 6 週間継続していた。

被毛光沢なく栄養状態不良, 左右両肺野に著明な乾性 ラッセル音聴取. 体温 $39^{\circ} \mathrm{C}$, 血液検査結果では著しい左方 変移がみられた。重篤な慢性肺炎として抗生剂による治 療を行ならも効果なく, 試験切開により腫瘍塊を確認, 生検により癌腫と診断した。

肺は胸廓全体に拈よび，一部をのぞいて，暗扊色で硬 く, 割面は瀮漫性白色結節がみられた。心臓, 横隔膜, 第 1 胃, 小腸, 脾蔵, 腎, 副腎にも結節がみられた. 組 織学的検索の結果, 気管枝壁に原発し, リンパ系を介し て転移したものと考光られる。縦隔膜りンパ，心筋など の転移病巣も, 原発巣と同様な組織像を呈していた。 